\title{
3-Iodothyronamine metabolism and functional effects in FRTL5 thyroid cells
}

\author{
Patrizia Agretti, Giuseppina De Marco, Laura Russo, Alessandro Saba', \\ Andrea Raffaelli ${ }^{2}$, Maja Marchini ${ }^{1}$, Grazia Chiellini ${ }^{1}$, Lucia Grasso, Aldo Pinchera, \\ Paolo Vitti, Thomas S Scanlan ${ }^{3}$, Riccardo Zucchi ${ }^{1}$ and Massimo Tonacchera \\ Dipartimento di Endocrinologia e Metabolismo, Centro Eccellenza AmbiSEN, Università di Pisa, Via Paradisa 2, 56124 Cisanello, Pisa, Italy \\ ${ }^{1}$ Dipartimento di Scienze dell'Uomo e dell'Ambiente, Sezione di Biochimica, Università di Pisa, Pisa, Italy \\ ${ }^{2} \mathrm{CNR}$ - Istituto di Chimica dei Composti Organo-Metallici, Pisa, Italy \\ ${ }^{3}$ Departments of Physiology and Pharmacology and Cell and Developmental Biology, Oregon Health and Science University, Portland, Oregon, USA
}

(Correspondence should be addressed to M Tonacchera; Email: mtonacchera@ hotmail.com)

\begin{abstract}
3-lodothyronamine ( $\left.T_{1} A M\right)$, produced from thyroid hormones $(T H)$ through decarboxylation and deiodination, is a potent agonist of trace amine-associated receptor 1 (TAAR1), a G protein-coupled receptor belonging to the family of TAARs. In vivo $\mathrm{T}_{1} \mathrm{AM}$ induces functional effects opposite to those produced on a longer time scale by $\mathrm{TH}$ and might represent a novel branch of $\mathrm{TH}$ signaling. In this study, we investigated the action of $\mathrm{T}_{1} \mathrm{AM}$ on thyroid and determined its uptake and catabolism using FRTL5 cells. The expression of TAAR1 was determined by PCR and western blot in FRTL5 cells, and CAMP, iodide uptake, and glucose uptake were measured after incubation with increasing concentrations of $T_{1} A M$ for different times. $T_{1} A M$ and its catabolites thyronamine $\left(T_{0} A M\right)$, 3-iodothyroacetic acid $\left(T A_{1}\right)$, and thyroacetic acid $\left(T A_{0}\right)$ were analyzed in FRTL5 cells by HPLC coupled to tandem mass spectrometry. The product of amplification of TAAR1 gene and TAAR1 protein was demonstrated in FRTL5 cells. No persistent and dose-dependent response to $T_{1} A M$ was observed after treatment with increasing doses of this substance for different times in terms of cAMP production and iodide uptake. A slight inhibition of glucose uptake was observed in the presence of $100 \mu \mathrm{M} \mathrm{T}{ }_{1} \mathrm{AM}$ after 60 and 120 min (28 and $32 \%$ respectively), but the effect disappeared after $18 \mathrm{~h} . \mathrm{T}_{1} \mathrm{AM}$ was taken up by FRTL5 cells and catabolized to $T_{0} A M, T A_{1}$, and $T A_{0}$ confirming the presence of deiodinase and amine oxidase activity in thyroid. In conclusion, $T_{1} A M$ determined a slight inhibition of glucose uptake in FRTL5 cells, but it was taken up and catabolized by these cells.
\end{abstract}

Journal of Molecular Endocrinology (2011) 47, 23-32

\section{Introduction}

Iodothyronines (including thyroid hormones $(\mathrm{TH})$ ) might be substrates for aromatic amino acid decarboxylase with production of iodothyronamines having structural similarities with several biogenic amines (Borowsky et al. 2001, Bunzow et al. 2001) present in trace levels in mammalian nervous system. Endogenously produced 3-iodothyronamine $\left(\mathrm{T}_{1} \mathrm{AM}\right)$ has been detected in human, rat, mouse, and guinea pig blood as well as other tissues (Scanlan et al. 2004, Saba et al. 2010). A specific group of mammalian G proteincoupled receptors, now called trace amine-associated receptors (TAARs), was recently discovered and classified (Borowsky et al. 2001, Bunzow et al. 2001). In humans, nine TAAR genes, including three pseudogenes, have been identified (Gloriam et al. 2005, Lewin 2006). The entire family of TAAR genes maps to a narrow region of a single chromosome spanning about $109 \mathrm{~kb}$ of human chromosome 6q23.1, $192 \mathrm{~kb}$ of mouse chromosome $10 \mathrm{~A} 4$, and $216 \mathrm{~kb}$ of rat chromosome 1p12 (Lindemann et al. 2005). Structural similarities among trace amines and iodothyronamines suggest that the latter are able to activate TAARs; in fact, $\mathrm{T}_{1} \mathrm{AM}$ has been shown to be the most potent agonist stimulating cAMP production via activation of heterologously expressed mouse and rat TAAR1 (Scanlan et al. 2004).

In target tissues, thyroxine $\left(\mathrm{T}_{4}\right)$, the predominant form of $\mathrm{TH}$, is enzymatically deiodinated to $3,5,3^{\prime}$ triiodothyronine $\left(\mathrm{T}_{3}\right)$, a high-affinity ligand for nuclear TH receptors controlling normal vertebrate development, growth, and metabolism (Yen 2001). $\mathrm{T}_{3}$-modulated transcription of target genes via activation of TH nuclear receptors is a slow process that requires hours or days. In addition to the classical nuclear mode of action of TH, a number of rapid effects at cytosol and plasma membrane levels have been identified (Davis \& Davis 1996, Falkenstein et al. 2000). These nongenomic actions of TH are extranuclear, independent of $\mathrm{TH}$ receptors, and occur at posttranscriptional level. It has been proposed that $\mathrm{T}_{1} \mathrm{AM}$ is a novel signaling molecule

DOI: $10.1530 / J M E-10-0168$ Online version via http://www.endocrinology-journals.org 


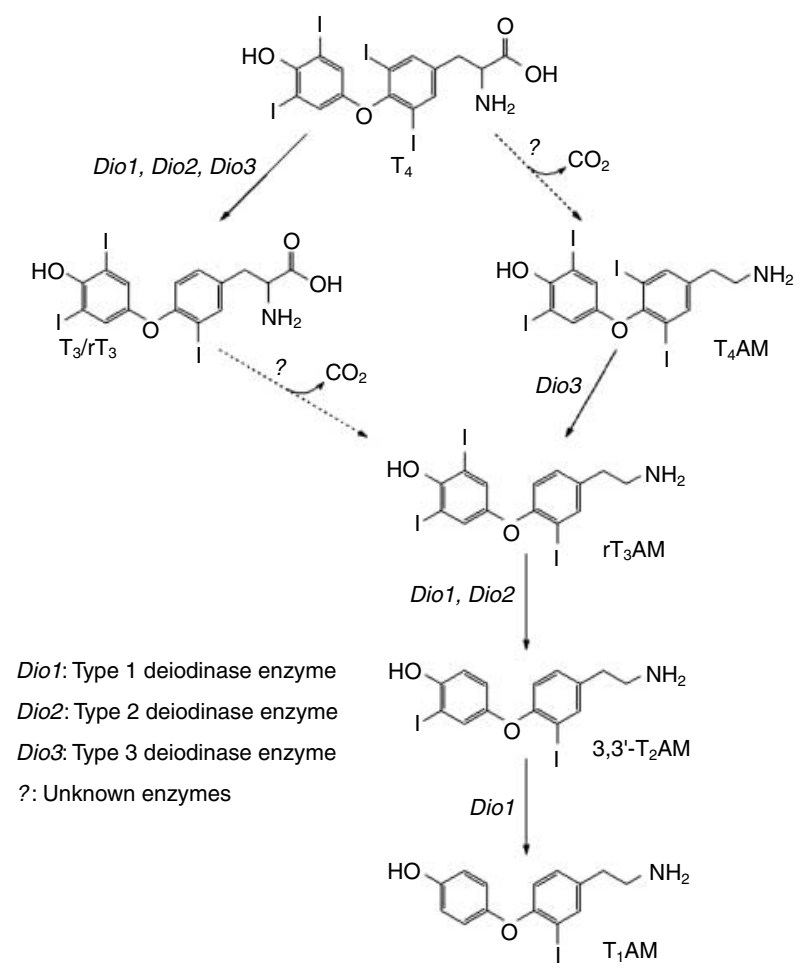

Figure 1 Proposed metabolic pathway of $T_{4}$ to $T_{1} A M$.

that can rapidly influence several physiological manifestations of $\mathrm{TH}$ action, including body temperature, heart rate, and cardiac output (Scanlan et al. 2004, Chiellini et al. 2007, Ghelardoni et al. 2009). In vivo, $\mathrm{T}_{1} \mathrm{AM}$ induces profound hypothermia and bradycardia within minutes, consequences that are opposite to those associated with TH excess, and it has been hypothesized that $\mathrm{T}_{1} \mathrm{AM}$ exerts its influence via nongenomic effectors including TAAR1 (Scanlan et al. 2004).

$\mathrm{T}_{1} \mathrm{AM}$ is usually assumed to be produced from $\mathrm{TH}$ through decarboxylation and deiodination (Zucchi et al. 2006), but there is no direct demonstration of $\mathrm{T}_{4}$ conversion to $\mathrm{T}_{1} \mathrm{AM}$ (Fig. 1). $\mathrm{T}_{1} \mathrm{AM}$ is a substrate of deiodinases, particularly D3 deiodinase (Piehl et al. 2008), and it is a potential substrate of amine oxidases, such as monoamine oxidase and semicarbazidesensitive amine oxidase. Oxidative deamination followed by aldehyde oxidation by the ubiquitous enzyme aldehyde dehydrogenase would produce 3-iodothyroacetic acid $\left(\mathrm{TA}_{1}\right.$; Scanlan et al. 2004, Gereben et al. 2008, Klieverik et al. 2009). Although $\mathrm{TA}_{1}$ production has been observed in hepatic tissue and cardiac tissue after administration of exogenous $T_{1-}$ AM (Wood et al. 2009, Saba et al. 2010), a quantitative and comprehensive analysis of $\mathrm{T}_{1} \mathrm{AM}$ catabolism (Fig. 2) in thyrocytes has not been performed.

In this study, we investigated the possible action of $\mathrm{T}_{1} \mathrm{AM}$ on thyroid by using a differentiated thyroid follicular cell line derived from normal rat thyroid (FRTL5 cells). In particular, we investigated the effects of $\mathrm{T}_{1} \mathrm{AM}$ on basal and bovine TSH (bTSH)-stimulated cAMP production and iodide and glucose uptake. Moreover, we evaluated whether exogenous $\mathrm{T}_{1} \mathrm{AM}$ can be taken up and/or catabolized by FRTL5 cells measuring the levels of $\mathrm{T}_{1} \mathrm{AM}$ and its catabolites thyronamine $\left(\mathrm{T}_{0} \mathrm{AM}\right), \mathrm{TA}_{1}$, and thyroacetic acid $\left(\mathrm{TA}_{0}\right)$ in cell medium and lysate by liquid chromatography (LC) coupled to tandem mass spectrometry (MS/MS). Uptake and catabolism of exogenous $\mathrm{T}_{4}$ in FRTL5 cells was also investigated.

\section{Materials and methods}

\section{Cell culture}

FRTL5 cells (Fisher rat thyroid cells) were grown in Coon's modified Ham's F-12 medium supplemented with $5 \%$ calf serum, gentamicin $(50 \mu \mathrm{g} / \mathrm{ml})$, and a six-hormone mixture containing insulin $(1 \mu \mathrm{g} / \mathrm{ml})$, hydrocortison $\left(10^{-8} \mathrm{M}\right)$, transferrin $(5 \mu \mathrm{g} / \mathrm{ml})$, somatostatin $(10 \mathrm{ng} / \mathrm{ml})$, glycyl-L-histidyl-L-lysine $(10 \mathrm{ng} / \mathrm{ml})$, and bTSH $(1 \mathrm{mU} / \mathrm{ml})$ as described previously (Ambesi-Impiombato et al. 1980). All the reagents were purchased from Sigma Chemical Co. FRTL5 cells were seeded in 96-well plates for the determination of cAMP production, in 24-well plates for the measurement of iodide uptake, and in $60 \mathrm{~mm}$ diameter dishes for total RNA extraction. For glucose uptake experiments, FRTL5 cells were grown in 24-well plates in Coon's modified Ham's F-12 medium supplemented with $5 \%$ calf serum, gentamicin $(50 \mu \mathrm{g} / \mathrm{ml})$, and a three-hormone mixture containing insulin $(1 \mu \mathrm{g} / \mathrm{ml})$, transferrin $(5 \mu \mathrm{g} / \mathrm{ml})$, and bTSH (1 $\mathrm{mU} / \mathrm{ml})$.

Rat thyroid primary cells were obtained from a tissue explant as described previously (Chiovato et al. 1989).

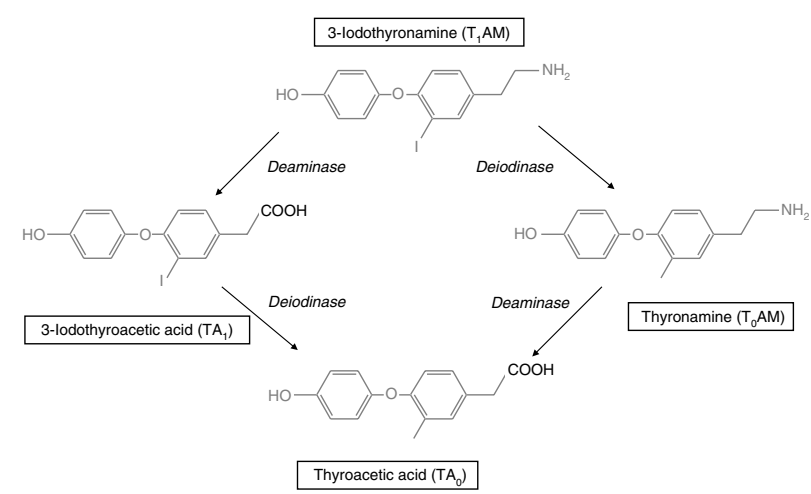

Figure 2 Chemical structure of 3-iodothyronamine $\left(T_{1} A M\right)$, thyronamine $\left(T_{0} A M\right)$, 3-iodothyroacetic acid $\left(T_{1}\right)$, and thyroacetic acid $\left(\mathrm{TA}_{0}\right)$. 
Total RNA extraction, DNase treatment, and reverse transcription

Total RNA was isolated directly from cultured FRTL5 cells and from rat and human thyroid tissues using the AquaPure RNA Isolation Kit (Bio-Rad Laboratories) according to the manufacturer's instructions. Contaminating DNA was removed by incubating the RNA for $15 \mathrm{~min}$ at $37^{\circ} \mathrm{C}$ with $0.5 \mu \mathrm{g}$ DNase I (Invitrogen Life Technologies) in the presence of a ribonuclease inhibitor. The quality of RNA samples was analyzed by microfluidic electrophoretic separation on chip using the Agilent 2100 BioAnalyzer (Agilent Technologies, Inc., Santa Clara, CA, USA). For each sample, $1 \mu \mathrm{g}$ of total RNA was reverse transcribed for $1 \mathrm{~h}$ at $42^{\circ} \mathrm{C}$ in a $20 \mu \mathrm{l}$ reaction volume using 200 units of Superscript II RNase $\mathrm{H}^{-}$reverse transcriptase (Invitrogen Life Technologies) in the presence of $1.5 \mu \mathrm{M}$ random examers (Pharmacia Biotech), 0.01 M dithiothreitol, and $1 \mathrm{mM}$ dNTP mix.

\section{PCR amplification}

The expression of rat TAAR1 mRNA was determined in FRTL5 cells and in rat and human thyroid tissues by PCR amplification. Reverse-transcribed cDNA (500 ng) was amplified using specific primers for a $300 \mathrm{bp}$ portion of rat TAARl gene or human TAAR1 gene. The sequences of primers are as follows: rTAAR1FW 5'-GTGAGAACAGTTGAGCA-3'; rTAAR1REV 5'-CGCAGGCAGAAGACCTGATT-3'; hTAAR1FW 5'-ATGGTGAGATCTGCTGAGCA-3'; hTAAR1REV 5'-TCCTCTGCAGTGAACATGTT-3'.

PCR amplification was carried out in $50 \mu \mathrm{l}$ reaction mixture containing $20 \mathrm{pM}$ specific primers and $1.5 \mathrm{mM}$ $\mathrm{MgCl}_{2}$ in the presence of $1 \mathrm{U}$ Taq DNA Polymerase (Invitrogen Life Technologies). After the amplification, $5 \mu \mathrm{l}$ reaction mix were separated on $1 \%$ agarose gel and the resulting bands were visualized in u.v. light on a transilluminator, following ethidium bromide staining. Molecular weights were compared with a 100 bp ladder.

\section{Protein extraction and western blot analysis}

Proteins were extracted from FRTL5 cells and rat tissues (brain, stomach and lung) and western blot analysis was performed as described previously (Peri et al. 2002). To detect TAAR1 in rat FRTL5 cells and in rat tissues used as positive controls, a polyclonal antibody raised against a peptide mapping within an extracellular domain of the protein was used (Santa Cruz Biotechnology, Inc., Santa Cruz, CA, USA).

\section{Trypan blue dye exclusion}

Cells (100 000) were grown in 24-well plates in sixhormone medium for 4-5 days and maintained for
6-7 days in five-hormone medium (in the absence of bTSH). Then, cells were incubated at $37^{\circ} \mathrm{C}$ for $1,6,24$, 48 , and $72 \mathrm{~h}$ with increasing concentrations of $\mathrm{T}_{1} \mathrm{AM}$ $(0 \cdot 1,1,10$, and $100 \mu \mathrm{M})$, with increasing concentrations of monoamine oxidase inhibitor pargyline $(1,10$, and $100 \mu \mathrm{M})$, or with increasing concentrations of the tyrosine kinase inhibitor genistein $(1,10$, and $100 \mu \mathrm{M})$. Cellular viability was determined with $0.2 \%$ trypan blue dye, and cell counts were performed using a hemocytometer. Results were expressed as percentage of alive cells with respect to the number of cells counted.

\section{Quantitative real-time PCR}

The expression level of type I iodothyronine deiodinase (Dio1) gene was determined in FRTL5 cells treated with $100 \mu \mathrm{M} \mathrm{T}_{1} \mathrm{AM}$ for $0-72 \mathrm{~h}$ by real-time PCR as reported previously (Agretti et al. 2002). After isolation of total RNA and reverse transcription, levels of Diol were measured using TaqMan gene expression assay (Rn00572183_m1; Applied Biosystems, Foster City, CA, USA). Analysis of relative gene expression data was performed using the $\Delta \Delta C_{\mathrm{T}}$ method with the housekeeping gene $\beta$-actin (Actb) as an endogenous control/ reference assay. Results were expressed as the amount of target gene normalized to the endogenous reference and relative to a calibrator (untreated FRTL5 cells).

\section{cAMP assay}

FRTL5 cells seeding in 96-well plates were grown for 4-5 days in six-hormone medium and 6-7 days in fivehormone medium before performing the cAMP assay. Cells were washed once with Hanks' balanced salt solution (HBSS) and incubated for 5, 15, 30, 60, 90, and $120 \mathrm{~min}$ at $37^{\circ} \mathrm{C}$ in hypotonic medium containing $0.5 \mathrm{mM}$ 3-isobutyl-1-methylxanthine (IBMX) as a cAMP phosphodiesterase inhibitor alone (basal value) or in the presence of increasing concentrations of bTSH (from 0.001 to $10 \mathrm{mU} / \mathrm{ml}$ ) or $\mathrm{T}_{1} \mathrm{AM}$ (from $0 \cdot 1$ to $100 \mu \mathrm{M})$. FRTL5 cells were also subjected to treatment with increasing concentrations of bTSH $(0 \cdot 01,0 \cdot 1,1$, 10 , and $100 \mathrm{mU} / \mathrm{ml}$ ) together with $0 \cdot 1,1$, and $10 \mu \mathrm{M}$ $\mathrm{T}_{1} \mathrm{AM}$. Additional experiments were performed in the presence of the monoamine oxidase inhibitor pargyline at the final concentration of $10 \mu \mathrm{M}$ for $60 \mathrm{~min}$. Extracellular cAMP was measured in the medium collected at the end of the incubation using an in-house RIA assay with a commercial polyclonal anti-cAMP antibody as described previously (Vitti et al. 1993) and expressed as pmoles per well.

\section{lodide uptake}

Cells (100 000) were plated in 24-well plates and grown for 4-5 days in six-hormone medium and 6-7 days in 
five-hormone medium before performing the $\mathrm{Na}^{125} \mathrm{I}$ uptake assay as described previously (Tonacchera $\mathrm{et}$ al. 2001). Briefly, cells were incubated at $37^{\circ} \mathrm{C}$ for $45 \mathrm{~min}$ with about 100000 c.p.m. of carrier-free $\mathrm{Na}^{125} \mathrm{I}$ (Amersham Biosciences) in the presence of $10 \mu \mathrm{M}$ $\mathrm{NaI}$, washed twice and solubilized with $0 \cdot 1 \mathrm{M} \mathrm{NaOH}$. The radioactivity from each well was counted using a $\gamma$-counter, and the data of iodide uptake were expressed as pmol/well. Iodide uptake was measured in FRTL5 cells after $6,12,24,36,48,60$, and $72 \mathrm{~h}$ of stimulation with $1 \mathrm{mU} / \mathrm{ml} \mathrm{bTSH}$ and after $24 \mathrm{~h}$ of treatment with increasing concentrations of bTSH. Time course of iodide uptake was also determined after treatment with increasing doses of $\mathrm{T}_{1} \mathrm{AM}$. Experiments were also performed in the presence of the monoamine oxidase inhibitor pargyline at the final concentration of $10 \mu \mathrm{M}$ or the tyrosine kinase inhibitor genistein at the final concentration of $37 \mu \mathrm{M}$.

\section{Glucose uptake}

FRTL5 cells were grown for 3 days in 24-well plates at a density of about $2 \times 10^{5}$ cells/well in three-hormone medium and were then grown for 7 days in onehormone medium (transferrin $5 \mu \mathrm{g} / \mathrm{ml}$ ) before performing ${ }^{3} \mathrm{H}$-deoxy-glucose $\left({ }^{3} \mathrm{H}-\mathrm{DG}\right)$ experiments.

Cells were quickly rinsed in $0.9 \% \mathrm{NaCl}$ and incubated for $2 \mathrm{~h}$ at $37^{\circ} \mathrm{C}$ with about $1 \mu \mathrm{Ci}$ 2-deoxy-D[1-3H]-glucose (Amersham Biosciences) in $500 \mu \mathrm{l}$ of uptake buffer (HBSS, 0.5\% BSA, $10 \mathrm{mM}$ Hepes, pH $7 \cdot 4)$. Finally, cells were rinsed three times in ice-cold uptake buffer and solubilized in $500 \mu \mathrm{l}$ RIPA buffer (50 mM Tris, pH 8.0, $150 \mathrm{mM} \mathrm{NaCl}, 1 \% \mathrm{NP}-40,0 \cdot 5 \%$ sodium deoxycholate, and $0 \cdot 1 \%$ SDS). In order to measure incorporated radioactivity, $450 \mu \mathrm{l}$ of each sample were removed and counted in a liquid scintillation $\beta$-counter (LKB Wallac, Turku, Finland). For protein quantity determination, $20 \mu \mathrm{l}$ of each sample were used (Bradford 1976). All experiments were conducted in triplicate, and in order to study the specificity of the glucose transporter-mediated uptake, we incubated cells from two wells in the same conditions as described above, but with the addition of $50 \mu \mathrm{M}$ cytochalasin B (Sigma-Aldrich). The values of radioactivity expressed in counts per minute were normalized with respect to the value of protein concentration and results were expressed as fmol ${ }^{3} \mathrm{H}-\mathrm{DG} / \mathrm{mg}$ protein.

${ }^{3} \mathrm{H}-\mathrm{DG}$ uptake was measured in FRTL5 cells after 0,5 , 30,60 , and $120 \mathrm{~min}$ and 18,24 , and $42 \mathrm{~h}$ of incubation with $10 \mathrm{mU} / \mathrm{ml} \mathrm{bTSH}$ and after $0,5,30,60$, and $120 \mathrm{~min}$ and $18 \mathrm{~h}$ of incubation with $\mathrm{T}_{1} \mathrm{AM} 100 \mu \mathrm{M}$. Experiments were also performed in the presence of the monoamine oxidase inhibitor pargyline at the final concentration of $10 \mu \mathrm{M}$ or the tyrosine kinase inhibitor genistein at the final concentration of $37 \mu \mathrm{M}$.

\section{$T_{1} A M$ and $T_{4}$ uptake and catabolism}

FRTL5 cells were seeded into 24-well plates and grown in six-hormone medium. At $80-90 \%$ confluence, the culture medium was replaced with $0.5 \mathrm{ml}$ of KrebsRinger medium (118 mM NaCl, $25 \mathrm{mM} \mathrm{NaHCO}$, $4.5 \mathrm{mM} \mathrm{KCl}, 1.2 \mathrm{mM} \mathrm{KH}_{2} \mathrm{PO}_{4}, 1.2 \mathrm{mM} \mathrm{MgSO}_{4}$, $1.5 \mathrm{mM} \mathrm{CaCl}_{2}$, and $11 \mathrm{mM}$ glucose) and cells were preincubated in a humidified atmosphere of $5 \% \mathrm{CO}_{2}$ at $37^{\circ} \mathrm{C}$ for $30 \mathrm{~min}$. Incubation started by adding $0.5 \mathrm{ml}$ Krebs-Ringer buffer containing $1 \mu \mathrm{M} \mathrm{T}_{1} \mathrm{AM}$ or $1 \mu \mathrm{M} \mathrm{T}_{4}$ and returning the plate to a humidified atmosphere of $5 \% \mathrm{CO}_{2}$ at $37^{\circ} \mathrm{C}$ for times ranging from $5 \mathrm{~min}$ to $24 \mathrm{~h}$. At the end of incubation, the medium was removed
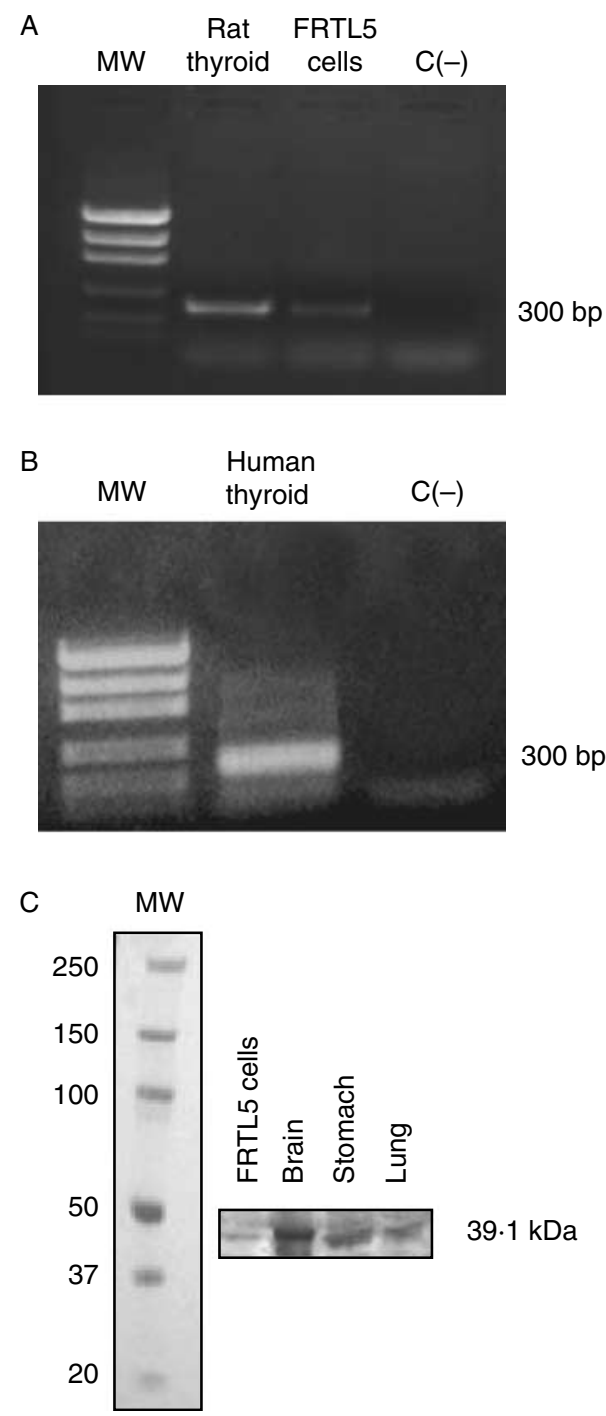

Figure 3 Rat and human TAAR1 expression. RT-PCR expression in FRTL5 cells and rat thyroid tissue $(A)$ and in human thyroid tissue (B); protein expression determined by western blot (C) in FRTL5 cells and in rat control tissues. 
from each well and transferred to a tube for HPLCMS/MS analysis. Cells adherent to plate were dissolved in $0.1 \mathrm{ml} \mathrm{NaOH} 0 \cdot 1 \mathrm{M}$ and $0.01 \mathrm{ml} 1.0 \mathrm{M} \mathrm{HCl}$ were added for $\mathrm{pH}$ neutralization. Cell lysates were then diluted with $0 \cdot 390 \mathrm{ml}$ of Krebs-Ringer medium, transferred to a tube for LC/MS/MS analysis, and centrifuged at $14000 \mathrm{~g}$ for 2-3 min before performing the analysis. Rat thyroid primary cells were grown and treated as above to investigate $\mathrm{T}_{4}$ uptake.

\section{HPLC-MS/MS}

To evaluate the metabolism of $\mathrm{T}_{1} \mathrm{AM}$ and $\mathrm{T}_{4}$, we modified previously published methods (Scanlan et al. 2004, Tai et al. 2004, Chiellini et al. 2007, Piehl et al. 2008) to develop an assay based on MS/MS coupled to HPLC, which allowed the contemporary detection of $\mathrm{T}_{3}, \mathrm{~T}_{4}, \mathrm{~T}_{1} \mathrm{AM}$, and its putative metabolites, namely $\mathrm{T}_{0} \mathrm{AM}, \mathrm{TA}_{0}$, and $\mathrm{TA}_{1}$. The assay technique has been described in detail elsewhere (Saba et al. 2010).

\section{Statistical analysis}

Results were expressed as mean \pm s.D. Differences between groups were evaluated by either one-way or two-way ANOVA as appropriate. If ANOVA showed significant differences between groups, individual groups were compared with the control group by Bonferroni post hoc test. GraphPad Prism version 4.1 for Windows (GraphPad Software, San Diego, CA, USA) was used for data analysis.

\section{Results}

\section{PCR amplification of TAAR1 gene}

Reverse transcription and PCR using specific primers for rat TAAR1 gene demonstrated the amplification product of about $300 \mathrm{bp}$ in FRTL5 cells and in rat thyroid tissue (Fig. 3A). RT-PCR analysis also showed the expression of nine different TAAR subtypes (TAAR2, TAAR3, TAAR4, TAAR5, TAAR6, TAAR7a, TAAR8a, and TAAR9) in FRTL5 cells (data not shown). The amplification product of human TAAR1 gene was also demonstrated in human thyroid tissue (Fig. 3B).

\section{TAAR1 protein expression determined by western blotting}

TAAR1 protein was detected in FRTL5 cells using a polyclonal antibody. TAAR1 protein corresponding to a $39 \cdot 1 \mathrm{kDa}$ band was identified in FRTL5 cells extract and in rat control tissues extracts (Fig. 3C).

\section{Trypan blue dye exclusion}

In this assay, no substance $\left(\mathrm{T}_{1} \mathrm{AM}\right.$, pargyline, and genistein) showed a cytotoxic effect at the tested doses (data not shown) on FRTL5 cells, and concentrations used for further experiments did not interfere with cell functions.

\section{Quantitative real-time PCR}

In order to assess whether intracellular $\mathrm{T}_{3}$ pathway could be altered by $\mathrm{T}_{1} \mathrm{AM}$, Diol gene expression was analyzed by quantitative PCR. Dio1 was expressed in FRTL5 cells and no significant change in expression level was observed after incubation with $100 \mu \mathrm{M} \mathrm{T}_{1} \mathrm{AM}$ for a period of time ranging from 0 to $72 \mathrm{~h}$ (data not shown).

\section{CAMP production after bTSH or $\mathrm{T}_{1}$ AM treatment}

Time course of cAMP production in FRTL5 cells after stimulation with increasing concentrations of bTSH
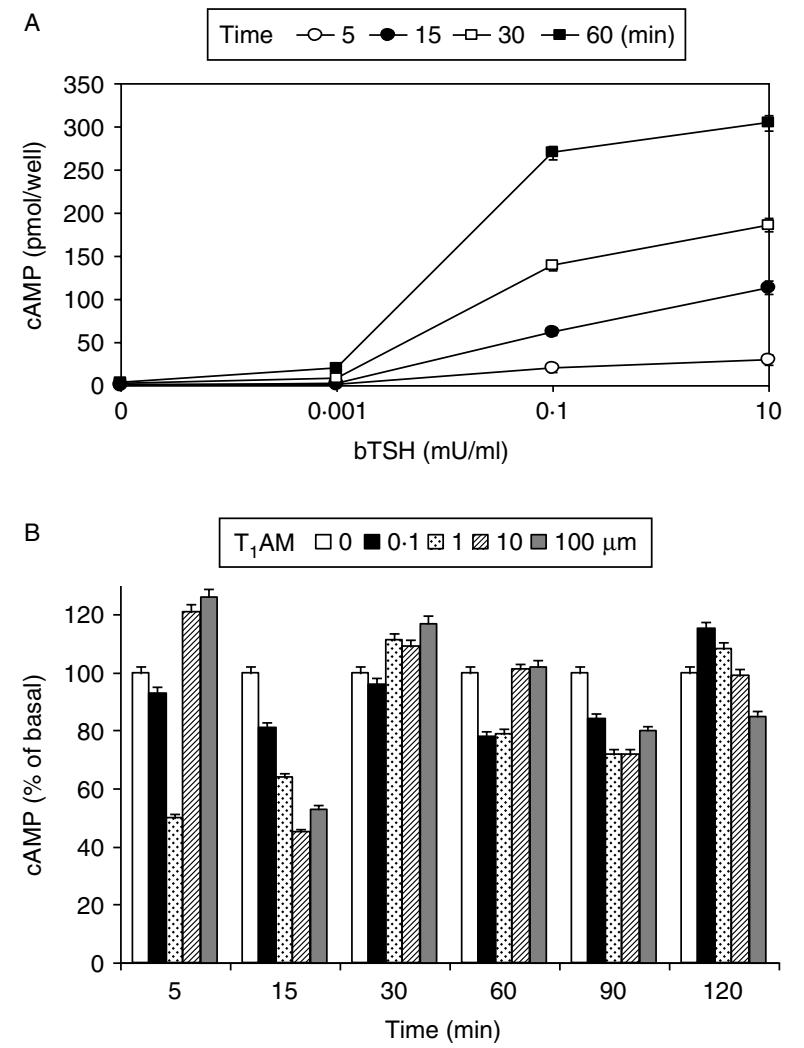

Figure 4 Time course of cAMP production in FRTL5 cells after stimulation with increasing concentrations of bTSH (A) and after stimulation with increasing concentrations of $T_{1} A M(B)$. When error bars are not visible, they are so small that they fall within the symbols. Data are expressed as mean \pm s.D. of three different experiments. 


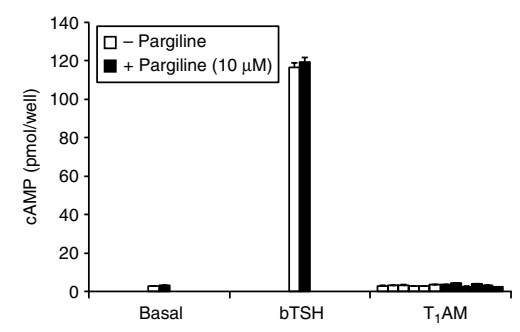

Figure 5 Effects of the monoamine oxidase inhibitor pargyline on cAMP production after bTSH $(10 \mathrm{mU} / \mathrm{ml})$ or $\mathrm{T}_{1}$ AM $(0.001,0.01$, $0 \cdot 1,1,10$, and $100 \mu \mathrm{M})$ treatment. When error bars are not visible, they are so small that they fall within the symbols. Data are expressed as mean \pm s.D. of three different experiments.

showed that the maximum response to bTSH was obtained after $60 \mathrm{~min}$ of incubation (Fig. 4A). No significant response to $T_{1} A M$ stimulation, in terms of cAMP production, was observed after treatment of FRTL5 cells with increasing doses of this substance for times ranging from 5 to $120 \mathrm{~min}$ as shown in Fig. 4B ( $P=\mathrm{NS}$ for the effect of $\mathrm{T}_{1} \mathrm{AM}$ by two-way ANOVA). Concentrations of $\mathrm{T}_{1} \mathrm{AM}$ ranging from $0 \cdot 1$ to $10 \mu \mathrm{M}$ were not able to modify the response of FRTL5 cells to stimulation with $0 \cdot 01-100 \mathrm{mU} / \mathrm{ml}$ bTSH (data not shown). The monoamine oxidase inhibitor pargyline was not able to modify the response to bTSH or $\mathrm{T}_{1} \mathrm{AM}$ stimulation in FRTL5 cells (Fig. 5).

\section{lodide uptake after bTSH or $\mathrm{T}_{1} \mathrm{AM}$ treatment}

Time course of iodide uptake in FRTL5 cells after stimulation with a maximal dose $(1 \mathrm{mU} / \mathrm{ml})$ of bTSH showed that a significant increase of iodide uptake was reached just after $24 \mathrm{~h}$ of treatment (Fig. 6A). The treatment of FRTL5 cells with increasing doses of bTSH for $24 \mathrm{~h}$ determined an increase of iodide uptake with a plateau reached at the concentration of $0.1 \mathrm{mU} / \mathrm{ml} \mathrm{bTSH} \mathrm{(Fig.} \mathrm{6B).} \mathrm{No} \mathrm{persistent} \mathrm{and}$ clearly dose-dependent response to $\mathrm{T}_{1} \mathrm{AM}$ stimulation was observed after treatment of FRTL5 cells with increasing doses of this substance for times ranging from 1 to $72 \mathrm{~h}$ (Fig. 6C). However, a slight reduction of iodide uptake occurred in the presence of 10 or $100 \mu \mathrm{M} \mathrm{T} \mathrm{T}_{1} \mathrm{AM}$ at 1 and $24 \mathrm{~h}(P<0 \cdot 01)$. The effect of $\mathrm{T}_{1} \mathrm{AM}$ on iodide uptake of FRTL5 cells was not increased in the presence of the monoamine oxidase inhibitor pargyline or the tyrosine kinase inhibitor genistein (data not shown).

\section{Glucose uptake after bTSH or $\mathrm{T}_{1} \mathrm{AM}$ treatment}

Treatment of FRTL5 cells with $10 \mathrm{mU} / \mathrm{ml} \mathrm{bTSH}$ for 5 , 30,60 , and $120 \mathrm{~min}$ and $18,24,42$, and $60 \mathrm{~h}$ determined an increase in ${ }^{3} \mathrm{H}-\mathrm{DG}$ uptake starting from $120 \mathrm{~min}$ and reaching the maximum plateau level after $42 \mathrm{~h}$ (Fig. 7A). No change in ${ }^{3} \mathrm{H}$-DG uptake was observed after treatment of FRTL5 cells with $100 \mu \mathrm{M} \mathrm{T}_{1} \mathrm{AM}$ for times ranging from 5 to $30 \mathrm{~min}$. Between 60 and $120 \mathrm{~min}$, a slight reduction of glucose uptake was observed $(P<0.05$ at $60 \mathrm{~min}$ and $P<0.01$ at $120 \mathrm{~min})$ but the effect was not persistent after $18 \mathrm{~h}$ (Fig. 7B). The effect of $\mathrm{T}_{1} \mathrm{AM}$ on ${ }^{3} \mathrm{H}-\mathrm{DG}$ uptake of FRTL5 cells was not increased in the presence of the monoamine oxidase inhibitor pargyline or the tyrosine kinase inhibitor genistein (data not shown).
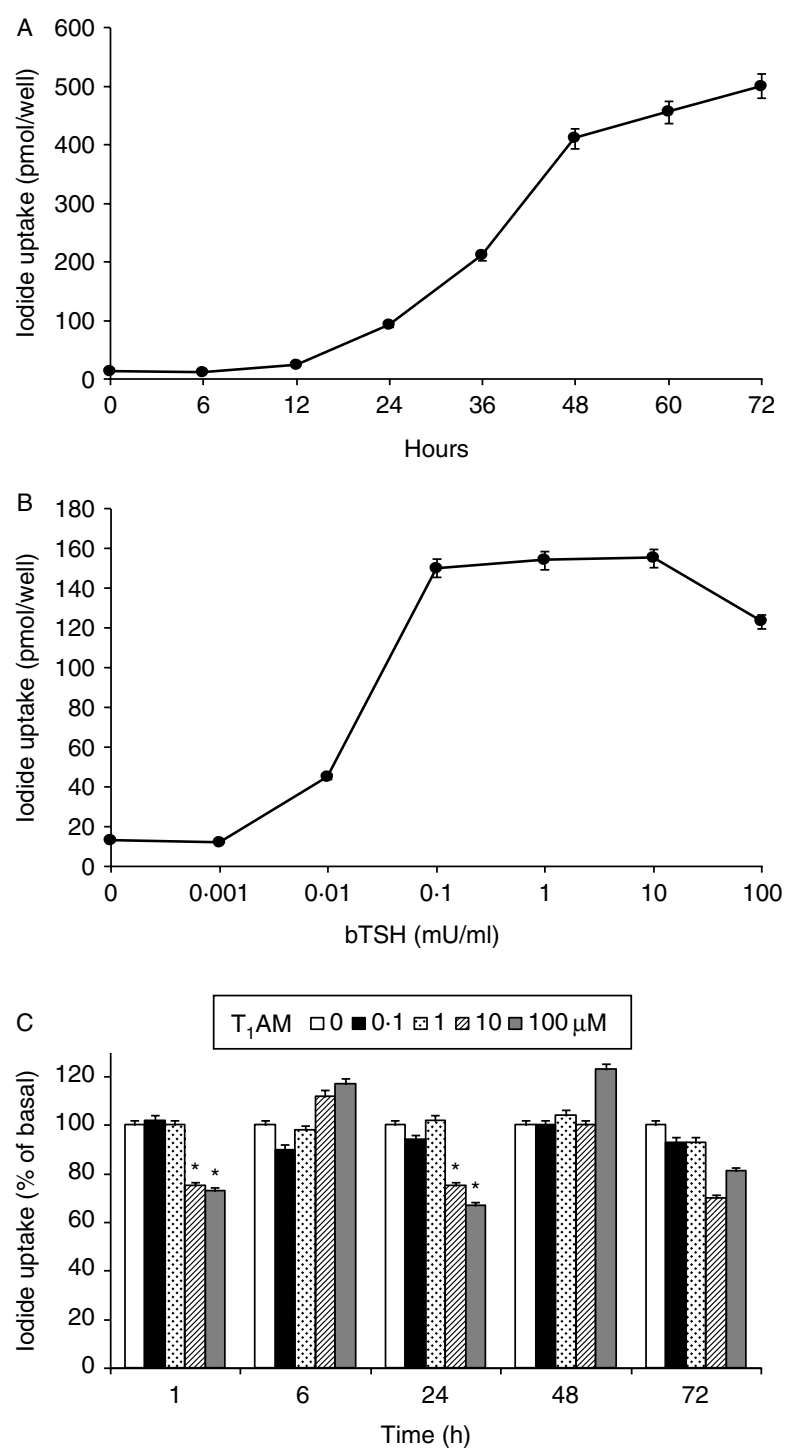

Figure 6 lodide uptake in FRTL5 cells after stimulation with $1 \mathrm{mU} / \mathrm{ml} \mathrm{bTSH}$ for different times (A), after $24 \mathrm{~h}$ treatment with increasing doses of bTSH (B), and after treatment with increasing concentrations of $T_{1} A M$ for different times $(C)$. When error bars are not visible, they are so small that they fall within the symbols. Data are expressed as mean \pm s.D. of three different experiments. 

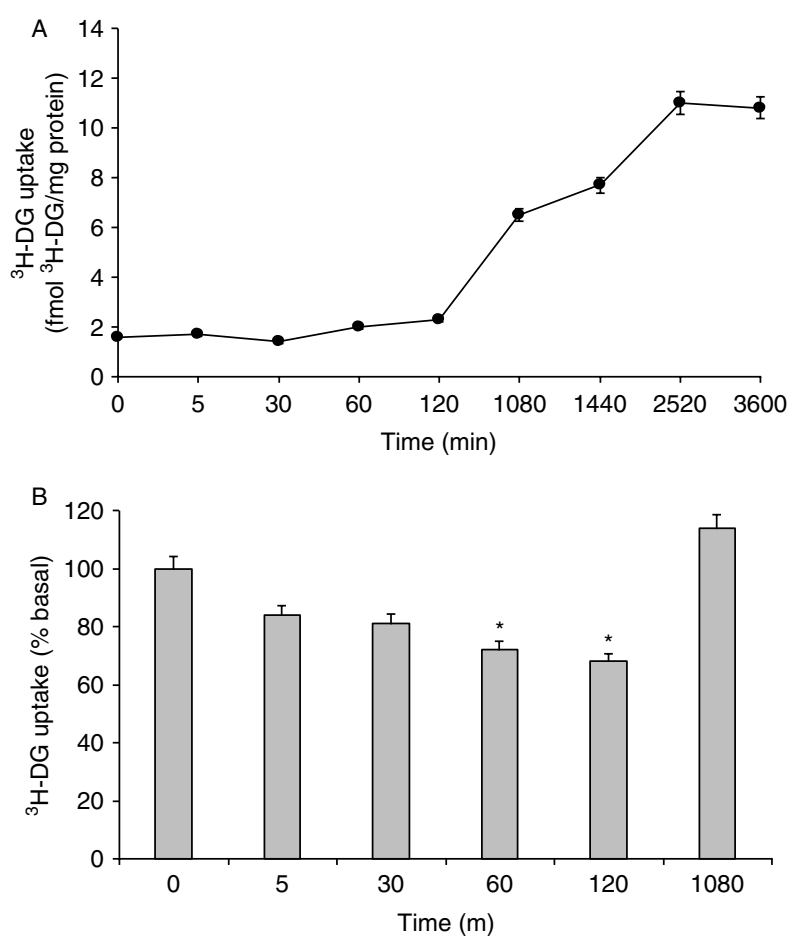

Figure 7 Glucose uptake in FRTL5 cells after treatment with $10 \mathrm{mU} / \mathrm{ml} \mathrm{bTSH}(\mathrm{A})$ and after treatment with $100 \mu \mathrm{M} \mathrm{T}_{1} \mathrm{AM}$ (B) for different times. When error bars are not visible, they are so small that they fall within the symbols. Data are expressed as mean \pm s.D. of three different experiments.

\section{$\mathrm{T}_{1} \mathrm{AM}$ and $\mathrm{T}_{4}$ uptake and catabolism in FRTL5 cells}

FRTL5 is a rat thyroid cell line, which does not express active thyroid peroxidase but has a high deiodinase activity (Borges et al. 1990, Derwahl et al. 1990). The results obtained in FRTL5 cells exposed to $1 \mu \mathrm{M}$ $\mathrm{T}_{1} \mathrm{AM}$ are shown in Fig. 8. In incubation medium, $\mathrm{T}_{1} \mathrm{AM}$ concentration decreased exponentially to zero, with a rate constant of $0 \cdot 156 \pm 0 \cdot 26 / \mathrm{min} \quad(r=$ $0 \cdot 975$ ), corresponding to a half-life of $4 \mathrm{~min}$. In cellular lysate, $\mathrm{T}_{1} \mathrm{AM}$ concentration showed complex changes: at first, it increased according to a first-order (hyperbolic) kinetics with $\mathrm{T}_{0.5}$ of $12 \cdot 25 \pm 3 \cdot 15 \mathrm{~min}(r=0 \cdot 958)$, peaked at $90 \mathrm{~min}(1.6 \mu \mathrm{M})$, and then progressively decreased reaching about $0.9 \mu \mathrm{M}$ at $360 \mathrm{~min}$. In pilot experiments, lysate $\mathrm{T}_{1} \mathrm{AM}$ concentration further decreased to $0.06 \mu \mathrm{M}$ after $1140 \mathrm{~min}$ of incubation. The assay of $\mathrm{T}_{1} \mathrm{AM}$ catabolites showed production of $\mathrm{T}_{0} \mathrm{AM}, \mathrm{TA}_{1}$, and $\mathrm{TA}_{0}$. Significant amounts of $\mathrm{T}_{0} \mathrm{AM}$ were detected only in cell lysate: a plateau was reached after 20-30 min, and then further increase occurred after $180 \mathrm{~min} . \mathrm{TA}_{1}$ and $\mathrm{TA}_{0}$ were detected mainly in the incubation medium, where their concentration increased over time and could be interpolated by linear regression. Over the first $180 \mathrm{~min}$ of the experiment lysate, $\mathrm{T}_{0} \mathrm{AM}$ concentration was about two orders of magnitude lower than $\mathrm{T}_{1} \mathrm{AM}$, and after $360 \mathrm{~min}$, it was still one order of magnitude lower. After $360 \mathrm{~min}$, the overall recovery, i.e. the ratio of $\left(\mathrm{T}_{1} \mathrm{AM}+\mathrm{T}_{0} \mathrm{AM}+\mathrm{TA}_{1}+\right.$ $\mathrm{TA}_{0}$ ) to initial $\mathrm{T}_{1} \mathrm{AM}$, was close to $100 \%$.

Figure 9A shows the results obtained in FRTL5 cells exposed to $1 \mu \mathrm{M} \mathrm{T}_{4}$. After $360 \mathrm{~min}$, the amount of $\mathrm{T}_{4}$ still present in the incubation medium was $71 \%$ of the initial dose. About $11 \%$ of the initial dose was detected in cell lysate, and $\mathrm{T}_{4}$ accumulation was roughly interpolated by a first-order (hyperbolic) kinetics with $\mathrm{T}_{0 \cdot 5}$ of $12 \cdot 87 \pm 6 \cdot 66 \mathrm{~min}(r=0 \cdot 671)$. About $21 \%$ of the administered $\mathrm{T}_{4}$ was converted into $\mathrm{T}_{3}$, giving a complete recovery, while other catabolites were not detected. $\mathrm{T}_{3}$ was detected both in the incubation medium and in the cellular lysate, and after $360 \mathrm{~min}$, the ratio of lysate $T_{3}$ to medium $T_{3}$ was close to 4 . In both compartments, the increase in $\mathrm{T}_{3}$ concentration was appropriately interpolated by polynomial or exponential fitting, with $r>0.980$.

Primary rat thyroid cells were also able to accumulate $\mathrm{T}_{4}$ and to produce a minimal amount of $\mathrm{T}_{3}$ when exposed to $1 \mu \mathrm{M} \mathrm{T}_{4}$ for times ranging from 0 to $360 \mathrm{~min}$ (Fig. 9B). Although $\mathrm{T}_{4}$ uptake was similar or even slightly higher in primary culture cells than in FRTL5 cells, $\mathrm{T}_{3}$ production was remarkably lower and corresponded to $<1 \%$ of the administered $\mathrm{T}_{4}$.

\section{Discussion}

It has recently been proposed that $\mathrm{T}_{0} \mathrm{AM}$, decarboxylated derivatives of $\mathrm{TH}$, may constitute a class of signaling molecules similar to several biogenic amines present in trace levels in mammalian nervous system, able to activate the members of a recently identified family of $\mathrm{G}$ protein coupled receptors (GPCRs) called TAARs. In particular, $\mathrm{T}_{1} \mathrm{AM}$ has been identified as the most potent agonist of the rat TAAR1 with an EC50 of $14 \mathrm{nM}$ (Scanlan et al. 2004). When heterologously expressed, rat or mouse TAAR1 rapidly couple to the stimulation of cAMP production when exposed to $\mathrm{T}_{1} \mathrm{AM}$. The types of $\mathrm{G}$ protein coupled to each TAAR and the immediate downstream effectors have yet to be established, although there is widespread evidence that activated recombinant TAAR1 heterologously expressed in HEK293 cells or Xenopus oocytes couple to Gs and stimulate cAMP production (Scanlan et al. 2004). In vivo $\mathrm{T}_{1} \mathrm{AM}$ has been found to produce physiological effects in a matter of minutes through a nontranscriptional mechanism, which are opposite to those induced over time by TH (Scanlan et al. 2004, Chiellini et al. 2007, Ghelardoni et al. 2009). Several authors reported TAAR transcripts to have a broad tissue distribution. The presence of TAAR1 mRNA was detected using in situ hybridization histochemistry in many areas of the mouse brain (Borowsky et al. 2001). 

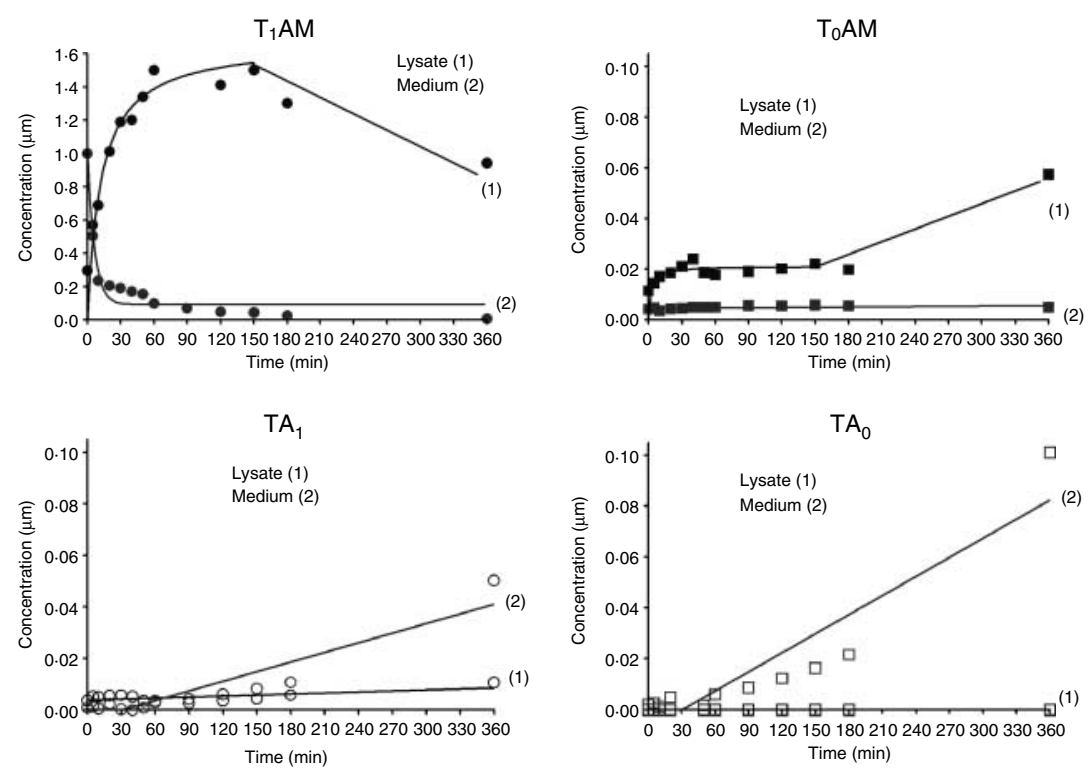

Figure 8 Representative experiments showing $\mathrm{T}_{1} \mathrm{AM}$ uptake and catabolism in FRTL5 cells. $T_{1} A M, T_{0} A M, T A_{1}$, and $T A_{0}$ concentrations are measured in lysate (1) and medium (2) from FRTL5 cells. Please note that as cellular lysate was diluted by about 25 -fold (Saba et al. 2010), actual cellular concentrations are about 25-fold higher than lysate concentrations.

Using quantitative RT-PCR, the same authors found that TAAR1 gene was expressed at moderate levels in human stomach and at low levels in human amygdala, kidney, lung, and small intestine. Trace amounts of TAAR1 mRNA were detected in human liver, pancreas, prostate, skeletal muscle, spleen, and in many areas of central nervous system (Borowsky et al. 2001). Recently, the expression of mRNA for TAAR1, TAAR6, TAAR8, and TAAR9 was demonstrated by RT-PCR in human leukocytes (D'Andrea et al. 2003), and TAAR9 was also
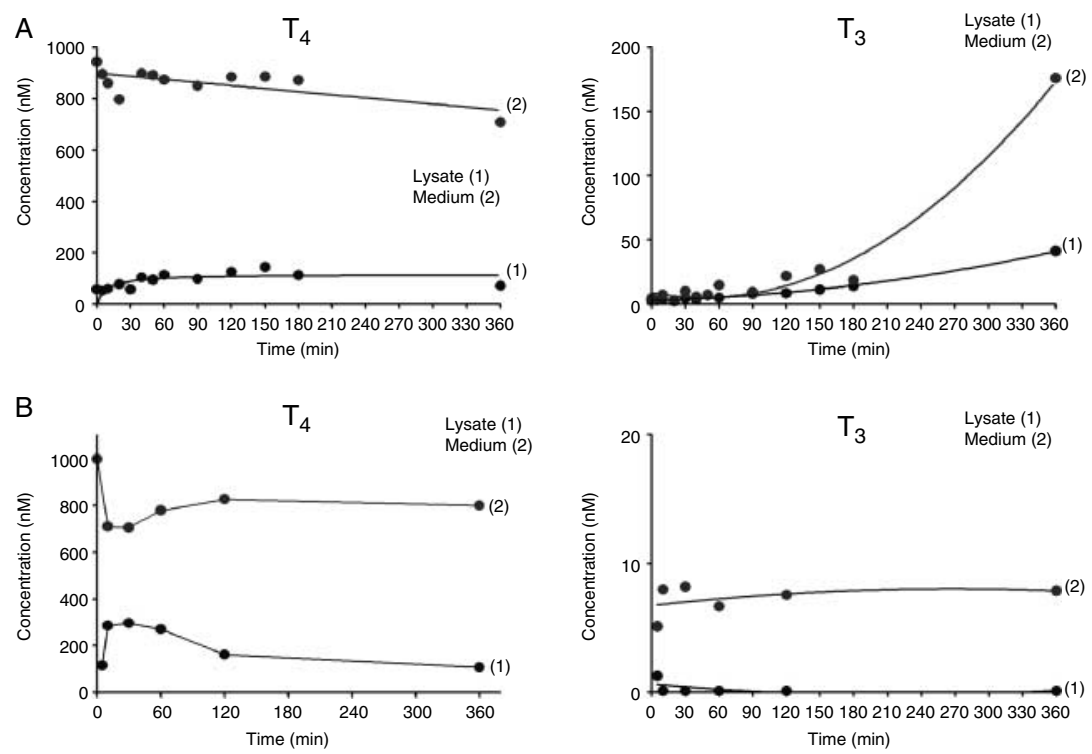

Figure 9 Representative results showing $T_{4}$ uptake and catabolism in FRTL5 cells $(A)$ and in cultured rat thyroid primary cells $(B)$. $T_{4}$ and $T_{3}$ concentrations were measured in lysate (1) and medium (2) from cells. Please note that as cellular lysate was diluted by about 25-fold (Saba et al. 2010), actual cellular concentrations are about 25-fold higher that lysate concentrations. 
found in pituitary and skeletal muscle (Vanti et al. 2003). Transcripts for TAAR1, TAAR2, TAAR3, TAAR4, and TAAR8a have been amplified from rat heart mRNA (Chiellini et al. 2007).

As we observed that TAAR1 gene is expressed in human thyroid tissue, we planned this study to investigate the possible action of $\mathrm{T}_{1} \mathrm{AM}$, the main agonist of TAAR1, on thyroid. We performed in vitro experiments on FRTL5 cells, a differentiated thyroid follicular cell line derived from normal rat thyroid, to investigate the effects of $\mathrm{T}_{1} \mathrm{AM}$ on basal and bTSHstimulated cAMP production and iodide and glucose uptake. The product of amplification of rat TAAR1 gene was demonstrated in FRTL5 cells by RT-PCR. The protein was also demonstrated in these cells by western blotting. Treatment of FRTL5 cells with increasing doses of $\mathrm{T}_{1} \mathrm{AM}$ for times ranging from few minutes to several hours was not able to produce major changes in cAMP production and iodide or glucose uptake. However, a transient decrease in glucose and possibly in iodide uptake was observed over a period of $1-2 \mathrm{~h}$ in the presence of $10-100 \mu \mathrm{M} \mathrm{T}_{1} \mathrm{AM}$. The monoamine oxidase inhibitor pargyline or the tyrosine kinase inhibitor genistein did not modify the effects of $\mathrm{T}_{1} \mathrm{AM}$ on FRTL5 cells. The noncytotoxic effect of $\mathrm{T}_{1} \mathrm{AM}$, pargyline, or genistein at the used concentrations, was determined with trypan blue dye.

The second issue, which we investigated, is $\mathrm{T}_{1} \mathrm{AM}$ accumulation and catabolism in FRTL5 cells. $\mathrm{T}_{1} \mathrm{AM}$ uptake has been reported in different neoplastic cell lines (Ianculescu et al. 2009) but has never been demonstrated in thyroid. The molecular mechanism responsible for $\mathrm{T}_{1} \mathrm{AM}$ uptake has not been defined, but it does not appear to involve known transporters for monoamines or TH. On the basis of transport inhibition by siRNA technique, eight candidate transporters belonging to the SLC family have recently been identified (Ianculescu et al. 2009). We obtained evidence that $\mathrm{T}_{1} \mathrm{AM}$ is accumulated by FRTL5 cells; since a few minutes after adding $\mathrm{T}_{1} \mathrm{AM}$ to the incubation medium, it could be detected in cellular lysate. Theoretical considerations suggest that $\mathrm{T}_{1} \mathrm{AM}$ may be a substrate for D1 and D3 deiodinases and for amine oxidases, so that expected catabolites include $\mathrm{T}_{0} \mathrm{AM}, \mathrm{TA}_{0}$, and $\mathrm{TA}_{1}$ (Zucchi et al. 2006, Gereben et al. 2008, Wood et al. 2009). To establish whether $\mathrm{T}_{1} \mathrm{AM}$ can undergo deiodination, experiments were performed with FRTL5 cells. This thyroid cell line cannot produce $\mathrm{TH}$, because thyroid peroxidase is not functional (Derwahl et al. 1990), but it shows higher deiodinase activity (either on the tyrosyl or on the phenolic ring) than normal thyroid tissue (Borges et al. 1990, Derwahl et al. 1990), as confirmed in the present investigation by determining Diol expression through quantitative PCR. In FRTL5, cellular uptake of $\mathrm{T}_{1} \mathrm{AM}$ was confirmed and deiodinated metabolites were detected. $\mathrm{T}_{0} \mathrm{AM}$ accumulated in the lysate, whereas $\mathrm{TA}_{1}$ and $\mathrm{TA}_{0}$ were released in the incubation medium. If the dilution of intracellular content in the lysate (over 25-fold) is taken into account, it seems likely that intracellular concentration exceeded extracellular concentration also for $\mathrm{TA}_{1}$ and $\mathrm{TA}_{0}$. These results are consistent with the known subcellular location of deiodinases and amino oxidases, because intracellular monoamine oxidase A (MAO-A) appears to be the prevailing amine oxidase in thyroid cells (Andres et al. 2001), and deiodination also occurs intracellularly (Friesema et al. 2006), although D3 is a plasma membrane enzyme (Gereben et al. 2008). Notably, the progressive decrease in $\mathrm{T}_{1} \mathrm{AM}$ concentration may account for the transient effects observed in functional experiments. Moreover, it was demonstrated that $\mathrm{T}_{4}$ enters in FRTL5 cells and is converted to a small extent to $T_{3}$, whereas other catabolites of $T_{4}$ are not detectable over this time scale. The intracellular $\mathrm{T}_{3}$ pathway was not altered by $\mathrm{T}_{1} \mathrm{AM}$, because the level of Dio1 expression was unchanged after prolonged exposure to $\mathrm{T}_{1} \mathrm{AM}$. As expected, $\mathrm{T}_{4}$ was also trapped and converted to $\mathrm{T}_{3}$ by normal rat thyroid primary cells. Although the extent of $\mathrm{T}_{4}$ uptake was similar in FRTL5 cells and in adult thyrocytes, $\mathrm{T}_{3}$ production was higher in the former model, consistent with a greater deiodinase activity.

In summary, we demonstrated that (i) TAAR1 is expressed in FRTL5 cells and in human thyroid tissue; (ii) its most potent agonist $\mathrm{T}_{1} \mathrm{AM}$ is not able to exert any effect on cAMP accumulation, while it may transiently decrease glucose uptake in FRTL5 cells; (iii) FRTL5 cells are able to accumulate, deiodinate, and oxidatively deaminate exogenous $\mathrm{T}_{1} \mathrm{AM}$; and (iv) FRTL5 are able to accumulate exogenous $\mathrm{T}_{4}$ and to convert it into $\mathrm{T}_{3}$.

\section{Declaration of interest}

The authors declare that there is no conflict of interest that could be perceived as prejudicing the impartiality of the research reported.

\section{Funding}

This work was supported by Ministero della Sanità, Ricerca Finalizzata: Indagine sulla associazione fra malattie congenite tiroidee e malattie neuropsichiche rare: studi genetico-molecolari e funzionali; Ministero dell'Istruzione, dell'Università e della Ricerca, PRIN 2008: Tironamine: misura nel siero di pazienti affetti da patologie tiroidee e metaboliche ed effetti in vitro su sistemi cellulari.

\section{References}

Agretti P, Chiovato L, De Marco G, Marcocci C, Mazzi B, SellariFranceschini S, Vitti P, Pinchera A \& Tonacchera M 2002 Real-time PCR provides evidence for thyrotropin receptor mRNA expression in orbital as well as in extraorbital tissues. European Journal of Endocrinology 147 733-739. (doi:10.1530/eje.0.1470733) 
Ambesi-Impiombato FS, Parks LA \& Coon HG 1980 Culture of hormone-dependent functional epithelial cells from rat thyroids. PNAS 77 3455-3459. (doi:10.1073/pnas.77.6.3455)

Andres N, Lizcano JM, Rodriguez MJ, Romera M, Unzeta M \& Mahy N 2001 Tissue activity and cellular localization of human semicarbazide-sensitive amine oxidase. Journal of Histochemistry and Cytochemistry 49 209-217. (doi:10.1177/002215540104900208)

Borges M, Ingbar SH \& Silva JE 1990 Iodothyronine deiodinase activity in FRTL5 cells: predominance of type I $5^{\prime}$-deiodinase. Endocrinology 126 3059-3068. (doi:10.1210/endo-126-6-3059)

Borowsky B, Adham N, Jones KA, Raddatz R, Artymyshyn R, Ogozalek KL, Durkin MM, Lakhlani PP, Bonini JA, Pathirana S et al. 2001 Trace amines: identification of a family of mammalian $\mathrm{G}$ proteincoupled receptors. PNAS 98 8966-8971. (doi:10.1073/pnas. 151105198)

Bradford MM 1976 A rapid and sensitive method for the quantitation of microgram quantities of protein utilizing the principle of protein-dye binding. Analytical Biochemistry 72 248-254. (doi:10. 1016/0003-2697(76)90527-3)

Bunzow JR, Sonders MS, Arttamangkul S, Harrison LM, Zhang G, Quigley DI, Darland T, Suchland KL, Pasumamula S, Kennedy JL et al. 2001 Amphetamine 3,4-methylenedioxymethamphetamine, lysergic acid diethylamide, and metabolites of the catecholamine neurotransmitters are agonists of a rat trace amine receptor. Molecular Pharmacology 60 1181-1188.

Chiellini G, Frascarelli S, Ghelardoni S, Carnicelli V, Tobias SC, DeBarber A, Brogioni S, Ronca-Testoni S, Cerbai E, Grandy DK et al. 2007 Cardiac effects of 3-iodothyronamine: a new aminergic system modulating cardiac function. FASEB Journal 21 1597-1608. (doi:10. 1096/fj.06-7474com)

Chiovato L, Vitti P, Cucchi P, Mammoli C, Carajon P \& Pinchera A 1989 The expression of the microsomal/peroxidase autoantigen in human thyroid cells is thyrotrophin-dependent. Clinical and Experimental Immunology 76 47-53.

D'Andrea G, Terrazzino S, Fortin D, Farruggio A, Rinaldi L \& Leon A 2003 HPLC electrochemical detection of trace amines in human plasma and platelets and expression of mRNA transcripts of trace amine receptors in circulating leukocytes. Neuroscience Letters 346 89-92. (doi:10.1016/S0304-3940(03)00573-1)

Davis PJ \& Davis FB 1996 Nongenomic actions of thyroid hormone. Thyroid 6 497-504. (doi:10.1089/thy.1996.6.497)

Derwahl M, Seto P \& Rapoport B 1990 An abnormal splice donor site in one allele of the thyroid peroxidase gene in FRTL5 rat thyroid cells introduces a premature stop codon: association with the absence of functional enzymatic activity. Molecular Endocrinology 4 793-799. (doi:10.1210/mend-4-6-793)

Falkenstein E, Tillmann HC, Christ M, Feuring M \& Wehling M 2000 Multiple actions of steroid hormones - a focus on rapid, nongenomic effects. Pharmacological Reviews 52 513-556.

Friesema EC, Kuiper GG, Jansen J, Visser TJ \& Kester MH 2006 Thyroid hormone transport by the human monocarboxylate transporter 8 and its rate-limiting role in intracellular metabolism. Molecular Endocrinology 20 2761-2772. (doi:10.1210/me.2005-0256)

Gereben B, Zavacki AM, Ribich S, Kim BW, Huang SA, Simonides WS, Zeöld A \& Bianco AC 2008 Cellular and molecular basis of deiodinase-regulated thyroid hormone signaling. Endocrine Reviews 29 898-938. (doi:10.1210/er.2008-0019)

Ghelardoni S, Suffredini S, Frascarelli S, Brogioni S, Chiellini G, Ronca-Testoni S, Grandy DK, Scanlan TS, Cerbai E \& Zucchi R 2009 Modulation of cardiac ionic homeostasis by 3-iodothyronamine. Journal of Cellular and Molecular Medicine 13 3082-3090. (doi:10. 1111/j.1582-4934.2009.00728.x)

Gloriam DE, Bjarnadóttir TK, Schiöth HB \& Fredriksson R 2005 High species variation within the repertoire of trace amine receptors. Annals of the New York Academy of Sciences 1040 323-327. (doi:10. 1196/annals.1327.052)
Ianculescu AG, Giacomini KM \& Scanlan TS 2009 Identification and characterization of 3-iodothyronamine $\left(\mathrm{T}_{1} \mathrm{AM}\right)$ intracellular transport. Endocrinology 150 1991-1999. (doi:10.1210/en.2008-1339)

Klieverik LP, Foppen E, Ackermans MT, Serlie MJ, Sauerwein HP, Scanlan TS, Grandy DK, Fliers E \& Kalsbeek A 2009 Central effects of thyronamines on glucose metabolism in rats. Journal of Endocrinology 201 377-386. (doi:10.1677/JOE-09-0043)

Lewin AH 2006 Receptors of mammalian trace amines. AAPS Journal 8 E138-E145. (doi:10.1208/aapsj080116)

Lindemann L, Ebeling M, Kratochwil NA, Bunzow JR, Grandy DK \& Hoener MC 2005 Trace amine-associated receptors form structurally and functionally distinct subfamilies of novel $\mathrm{G}$ proteincoupled receptors. Genomics 85 372-385. (doi:10.1016/j.ygeno. 2004.11.010)

Peri A, Luciani P, Tonacchera M, Agretti P, Baglioni-Peri S, Buci L, Conforti B, Cioppi F, Biliotti G, Serio M et al. 2002 Expression of cAMP-responsive element binding protein and inducible cAMP early repressor in hyperfunctioning thyroid adenomas. European Journal of Endocrinology 146 759-766. (doi:10.1530/eje.0.1460759)

Piehl S, Heberer T, Balizs G, Scanlan TS, Smits R, Koksch B \& Köhrle J 2008 Thyronamines are isozyme-specific substrates of deiodinases. Endocrinology 149 3037-3045. (doi:10.1210/en.2007-1678)

Saba A, Chiellini G, Frascarelli S, Marchini M, Ghelardoni S, Raffaelli A, Tonacchera M, Vitti P, Scanlan TS \& Zucchi R 2010 Tissue distribution and cardiac metabolism of 3-iodothyronamine. Endocrinology 151 5063-5073. (doi:10.1210/en.2010-0491)

Scanlan TS, Suchland KL, Hart ME, Chiellini G, Huang Y, Kruzich PJ, Frascarelli S, Crossley DA, Bunzow JR, Ronca-Testoni S et al. 2004 3-Iodothyronamine is an endogenous and rapid-acting derivative of thyroid hormone. Nature Medicine 10 638-642. (doi:10.1038/ nm1051)

Tai SS-C, Bunk DM, White E \& Welch MJ 2004 Development and evaluation of a reference measurement procedure for the determination of total 3,5,3'-triiodothyronine in human serum using isotope-dilution liquid chromatography-tandem mass spectrometry. Analytical Chemistry 76 5092-5096. (doi:10.1021) ac049516h)

Tonacchera M, Agretti P, Ceccarini G, Lenza R, Refetoff S, Santini F, Pinchera A, Chiovato L \& Vitti P 2001 Autoantibodies from patients with autoimmune thyroid disease do not interfere with the activity of the human iodide symporter gene stably transfected in CHO cells. European Journal of Endocrinology 144 611-618. (doi:10.1530/ eje.0.1440611)

Vanti WB, Muglia P, Nguyen T, Cheng R, Kennedy JL, George SR \& O'Dowd BF 2003 Discovery of a null mutation in a human trace amine receptor gene. Genomics 82 531-536. (doi:10.1016/S08887543(03)00173-3)

Vitti P, Elisei R, Tonacchera M, Chiovato L, Mancusi F, Rago T, Mammoli C, Ludgate M, Vassart G \& Pinchera A 1993 Detection of thyroid-stimulating antibody using Chinese hamster ovary cells transfected with cloned human thyrotropin receptor. Journal of Clinical Endocrinology and Metabolism 76 499-503. (doi:10.1210/jc.76. 2.499)

Wood WJL, Geraci T, Nilsen A, DeBarber A \& Scanlan TS 2009 Iodothyronamines are oxidatively deaminated to iodothyroacetic acids in vivo. Chembiochem: a European Journal of Chemical Biology 26 361-365. (doi:10.1002/cbic.200800607)

Yen PM 2001 Physiological and molecular basis of thyroid hormone action. Physiological Reviews 81 1097-1142.

Zucchi R, Chiellini G, Scanlan TS \& Grandy DK 2006 Trace amineassociated receptors and their ligands. British Journal of Pharmacology 149 967-978. (doi:10.1038/sj.bjp.0706948)

Received in final form 29 March 2011

Accepted 21 April 2011

Made available online as an Accepted Preprint 21 April 2011 